\title{
STRUCTURAL ANALYSIS OF CREATIVE ECONOMIES IN THE CENTER DEVELOPMENT REGION
}

DOI: http://dx.doi.org/10.18509/GBP.2020.66

UDC: 332.122.055.2:711.4]:303.716(498)"2000/2016"

\author{
Andreea Karina Gruia ${ }^{1,2}$ \\ Alexandra Grecu',2 \\ Adrian-Gabriel Simion ${ }^{1,2}$ \\ Cristina Valeria Popescu ${ }^{1,2}$ \\ Irina Rădoi ${ }^{1,2}$ \\ ${ }^{1}$ University of Bucharest - Faculty of Geography, Romania \\ ${ }^{2}$ University of Bucharest - Research Center for Integrated \\ Analysis and Territorial Management (CAIMT), Romania
}

\begin{abstract}
Creative economies are an important indicator of sustainable regional development. The study follows the spatial dynamics of creative economies in the Center Development Region - one of the most important development regions of Romania.

The quantification of the spatial dynamics of the creative sector at the level of the region was made starting from an economic database, at the level of the territorial administrative unit, for the economic indicator relevant to this study - turnover. The analysis was carried out at the National Classification for the Economic Activities (NACE) level, for the period 2000-2016. The establishment of creative activities was made after the Government Decision no. 859 of 2014, which indicates, for this economic sector, a number of 66 codes, grouped into 7 main areas. Graphic models were developed and also a series of cartographic models using the open-source QGis platform.

The results of the study highlight a series of local specificities determined by the concentration of the main areas of the creative sector within polarizing urban centers, which support the development of creative activities in the region. Also, there is an increasing share of creative economies in emerging spaces.
\end{abstract}

Keywords: urban development, creative economies, spatial distribution

\section{INTRODUCTION}

The role and importance of creative economy is being studied more and more lately. The creative economy is considered to be a tool for urban and regional revitalization and regeneration and also, this type of economy is economy creates jobs and well-being [1]. Creativity becomes an economic activity only when an idea becomes a business [2].

It is considered that two types of capital are the basis of the growth of cities and regions, creative and social capital. The concept of creative capital was popularized by Florida [3]. According to him, the creative class - which includes professionals such as doctors, lawyers, scientists, engineers, university professors, but also artists, musicians and sculptors who own creative capital. This group produces ideas, information and technology and these are increasingly important for the growth of cities and regions [4]. The spatial patterns of the creative professions have led to a better understanding of the importance of place in modelling the local accumulation of the creative process [5], [6], [7], [8]. 
Recent studies consider the creative economy as a strategy for sustainable development and promoting regional development [9], as well as the fact that it can develop public policies aimed at preserving the quality of the city, increasing community prosperity, but also its historical development [10], [11].

The creative economy draws attention by the role that innovation activities plays at the level of companies in the creative sector [12], [13], [14], [15], [16] but also because of their connection with other economic sectors [17], [18]. It also contributes to innovation in other branches of the economy with the help of various creative contributions but also of human capital, which are the main vehicles for spreading innovation in other sectors [19], [20].

\section{METHODOLOGY}

\section{Area of study}

The study analyzes the spatial distribution and the dynamics of the creative economy at the level of the Center Development Region on the basis of an economic indicator turnover. The Center Development Region is located within the Romanian Carpathian arc, being saturated by the meridian $25^{\circ}$ East longitude and $46^{\circ}$ North latitude parallel, having radial links with 6 of the 7 development regions (Fig. 1).

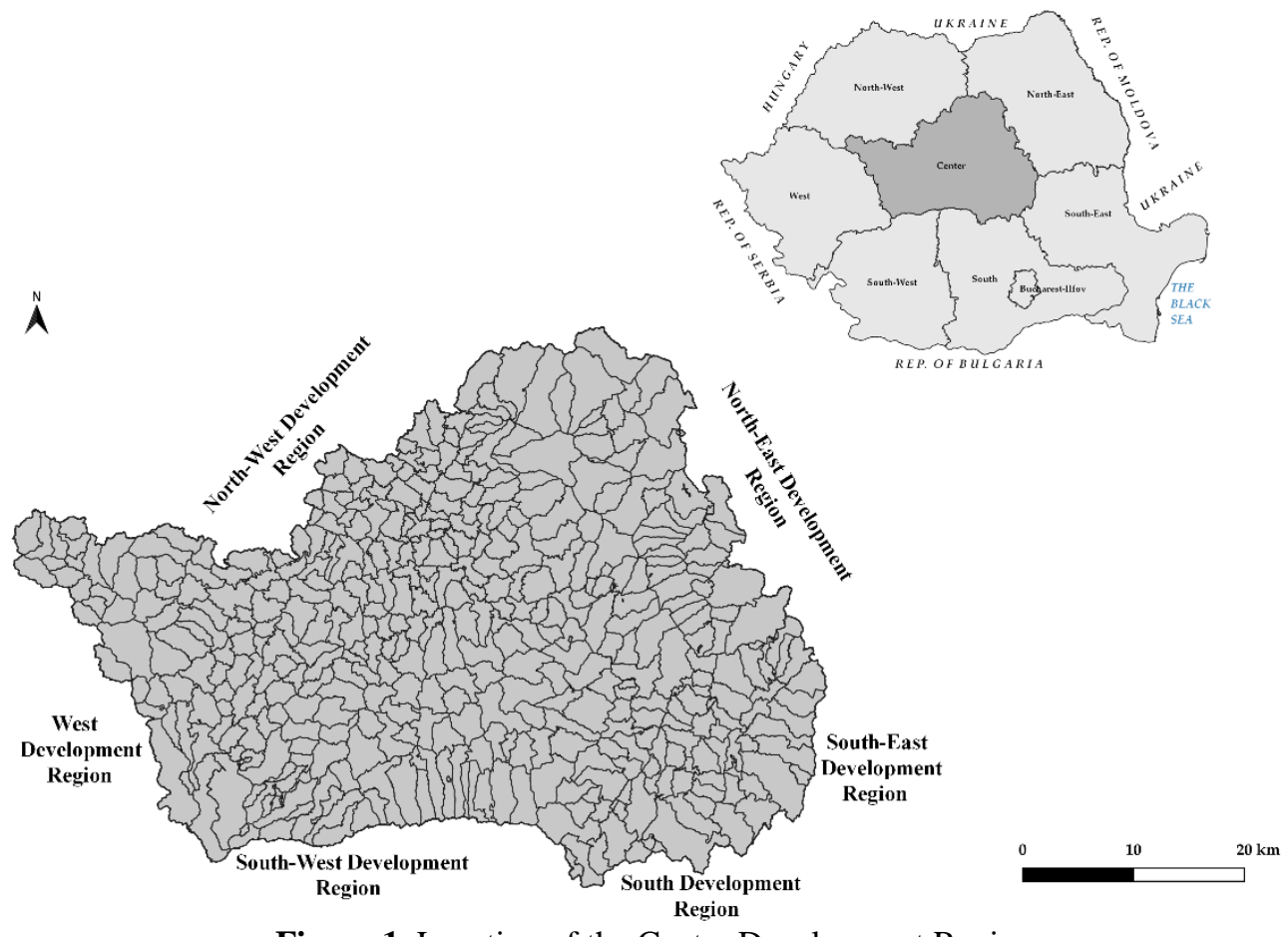

Figure 1. Location of the Center Development Region

\section{Data analysis}

The analysis period of the study is between 2000 and 2016. An economic database has been created at the level of administrative-territorial unit, highlighting an economic indicator relevant to the analysis of creative economies (turnover) according to the Classification of National Economy Activities (NACE). The NACE codes belonging to the creative economies were chosen accordingly to the Government Decision no. 859 of 2014, regarding the approval of the "Government Strategy for the development of the 
Table 1. Creative areas classification

\begin{tabular}{|c|c|c|}
\hline CLASS & NACE CODES & CREATIVE ACTIVITIES \\
\hline \multirow{7}{*}{ Publishing } & 5811 & Book publishing \\
\hline & 5812 & Publishing of directories and mailing lists \\
\hline & 5813 & Publishing of newspapers \\
\hline & 5814 & Publishing of journals and periodicals \\
\hline & 5819 & Other publishing activities \\
\hline & 5821 & Publishing of computer games \\
\hline & 5829 & Other software publishing \\
\hline \multirow{13}{*}{ Media and cinema } & 5911 & Motion picture, video and television programme production activities \\
\hline & 5912 & Motion picture, video and television programme post-production activities \\
\hline & 5913 & Motion picture, video and television programme distribution activities \\
\hline & 5914 & Motion picture projection activities \\
\hline & 5920 & Sound recording and music publishing activities \\
\hline & 6391 & News agency activities \\
\hline & 7311 & Advertising agencies \\
\hline & 7312 & Media representation \\
\hline & 7320 & Market research and public opinion polling \\
\hline & 7410 & Specialised design activities \\
\hline & 7420 & Photographic activities \\
\hline & 7430 & Translation and interpretation activities \\
\hline & 7490 & Other professional, scientific and technical activities n.e.c. \\
\hline \multirow{6}{*}{ IT } & 6202 & Computer consultancy activities \\
\hline & 6203 & Computer facilities management activities \\
\hline & 6209 & Other information technology and computer service activities \\
\hline & 6311 & Data processing, hosting and related activities \\
\hline & 6312 & Web portals \\
\hline & 6399 & Other information service activities n.e.c. \\
\hline \multirow{3}{*}{$\begin{array}{l}\text { Architecture and } \\
\text { engineering }\end{array}$} & 7111 & Architectural activities \\
\hline & 7112 & Engineering activities and related technical consultancy \\
\hline & 7120 & Technical testing and analysis \\
\hline \multirow{14}{*}{$\begin{array}{c}\text { Education and } \\
\text { research }\end{array}$} & 7211 & Research and experimental development on biotechnology \\
\hline & 7219 & Other research and experimental development on natural sciences and engineering \\
\hline & 7220 & Research and experimental development on social sciences and humanities \\
\hline & 8510 & Pre-primary education \\
\hline & 8520 & Primary education \\
\hline & 8531 & General secondary education \\
\hline & 8532 & Technical and vocational secondary education \\
\hline & 8541 & Post-secondary non-tertiary education \\
\hline & 8542 & Tertiary education \\
\hline & 8551 & Sports and recreation education \\
\hline & 8552 & Cultural education \\
\hline & 8553 & Driving school activities \\
\hline & 8559 & Other education n.e.c. \\
\hline & 8560 & Educational support activities \\
\hline \multirow{9}{*}{ Health } & 8610 & Hospital activities \\
\hline & 8621 & General medical practice activities \\
\hline & 8622 & Specialist medical practice activities \\
\hline & 8623 & Dental practice activities \\
\hline & 8690 & Other human health activities \\
\hline & 8710 & Residential nursing care activities \\
\hline & 8720 & Residential care activities for mental retardation, mental health and substance abuse \\
\hline & 8730 & Residential care activities for the elderly and disabled \\
\hline & 8790 & Other residential care activities \\
\hline \multirow{14}{*}{$\begin{array}{l}\text { Culture and } \\
\text { recreation }\end{array}$} & 9001 & Performing arts \\
\hline & 9002 & Support activities to performing arts \\
\hline & 9003 & Artistic creation \\
\hline & 9004 & Operation of arts facilities \\
\hline & 9101 & Library and archives activities \\
\hline & 9102 & Museums activities \\
\hline & 9103 & Operation of historical sites and buildings and similar visitor attractions \\
\hline & 9104 & Botanical and zoological gardens and nature reserves activities \\
\hline & 9311 & Operation of sports facilities \\
\hline & 9312 & Activities of sports clubs \\
\hline & 9313 & Fitness facilities \\
\hline & 9319 & Other sports activities \\
\hline & 9321 & Activities of amusement parks and theme parks \\
\hline & 9329 & Other amusement and recreation activities \\
\hline
\end{tabular}


sector of small and medium-sized enterprises and the improvement of the business environment in Romania Horizon 2020". Based on the classifications made by Howkins [21], Florida [22] and The New England Council [23], was made a creative areas classification of the 66 NACE codes of the creative sector for Romania (Table 1.)

\section{GIS analysis}

An open-source software - QGIS 3.4 was used for to make maps for each year, for the period 2000-2016, for the value of turnover, in a sequential color scheme, at the level of territorial administrative unit.

\section{Graphical models}

The graphical models show the evolution of the values of turnover for the time span 20002016. The graphs show the evolution of the 7 classes (Publishing, Media and cinema, IT, Architecture and engineering, Education and research, Health and Culture and recreation) at national and regional level and also show the evolutions of the NACE codes that belong to the respective classes.

The values for turnover, for a better analysis, are expressed in the national currency (Lei), thus that at the course of the National Bank of Romania 1 euro represents 4.75 LEI.

\section{RESULTS}

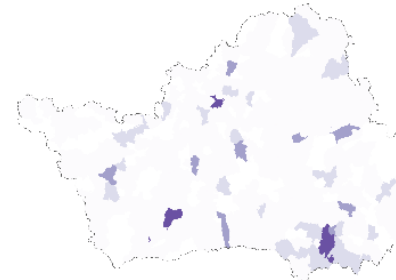

2000

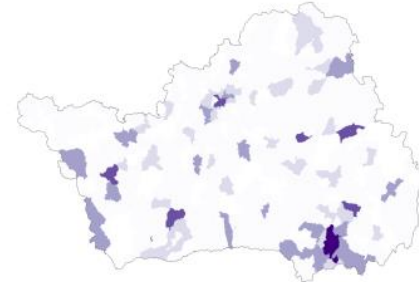

2003

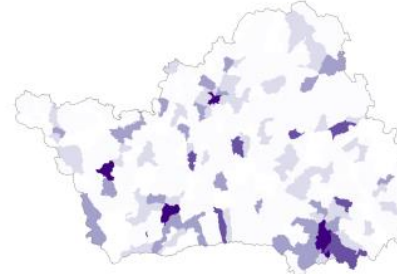

2006

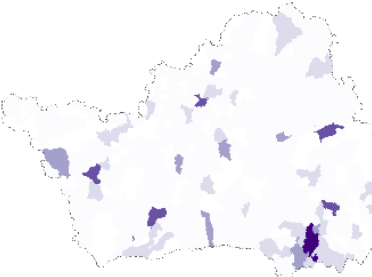

2001

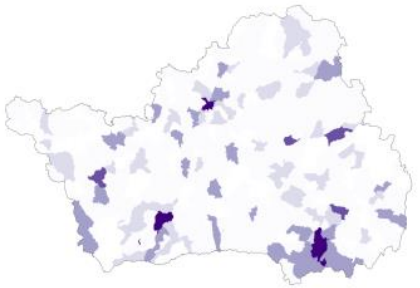

2004

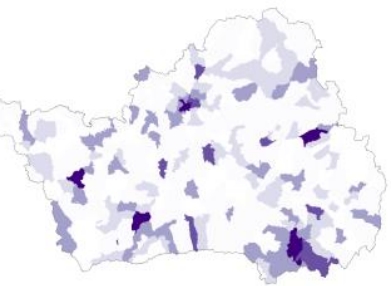

2007

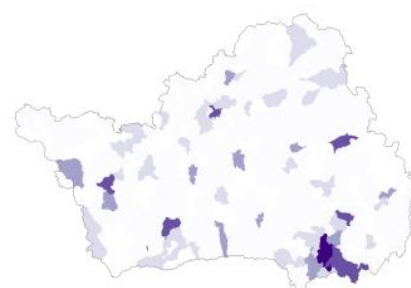

2002

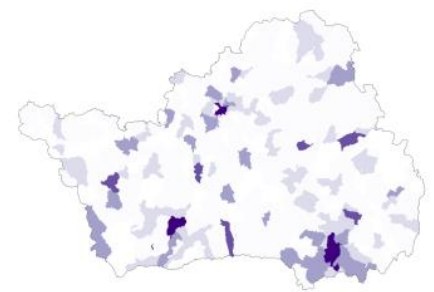

2005

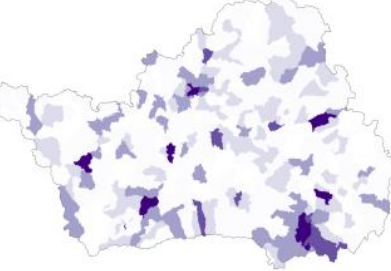

2008 


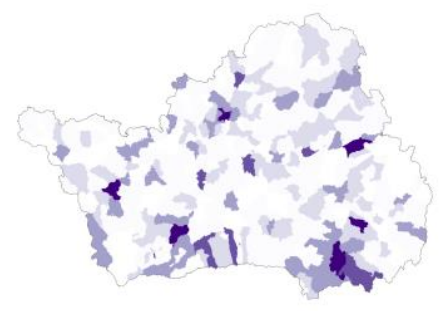

2009

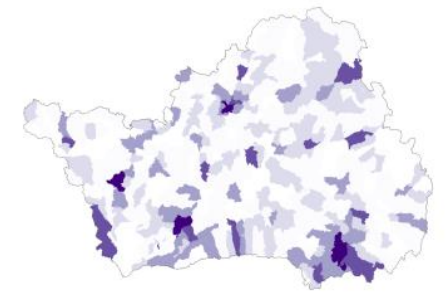

2012

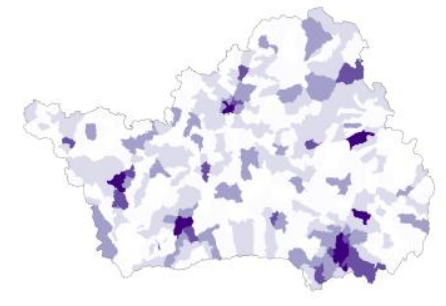

2015

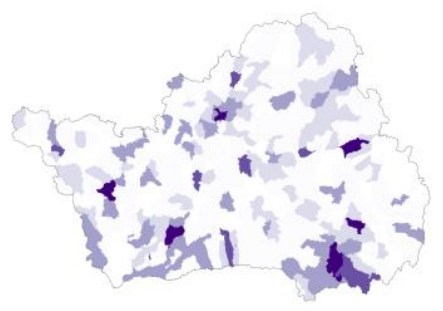

2010

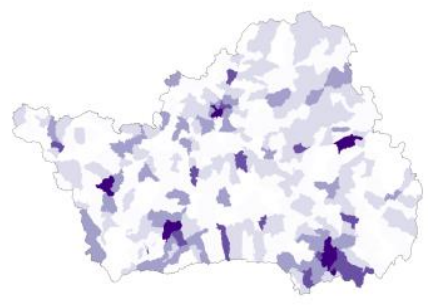

2013

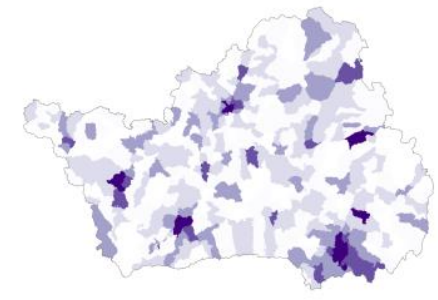

2016

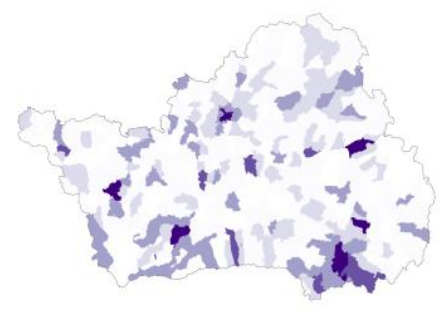

2011

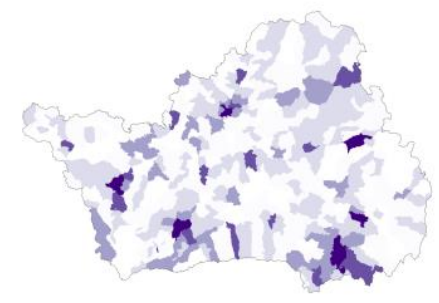

2014

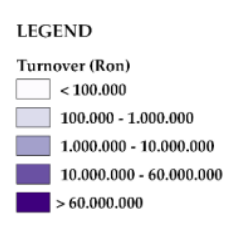

Figure 2. Spatial distribution of turnover in the creative sector for the Center Development Region Source: UB/1423

The spatial evolution of the turnover in the Center Development Region (Fig. 2) shows an upward evolution of values, with increases throughout the analyzed period. At regional level the main 3 cities with the highest turnover in the creative sector for the first reference year, 2000, are Brașov (with 2,325,471,420 lei), Târgu Mureș (with 1,433,429,392 lei) and Sibiu with a value of 1,068,526,023 lei. For the period 2008 (the installation of the economic crisis) - 2009 (when its effects are observed) the situation for the Development Region 7 remains unchanged (Brașov, Sibiu and Târgu Mureș having the most significant values). In 2009 there were slight decreases in values. In the last reference year, 2016, the values increase, reaching 26,946,369,348 lei (for Brașov), 16,526,785,839 lei (for Târgu Mureș) and 13,045,021,702 lei for Sibiu.

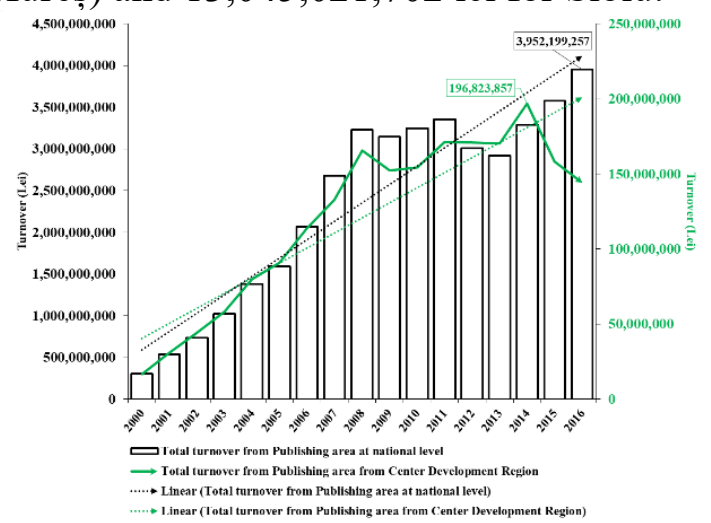

Figure 3. Evolution of the total turnover for Publishing area

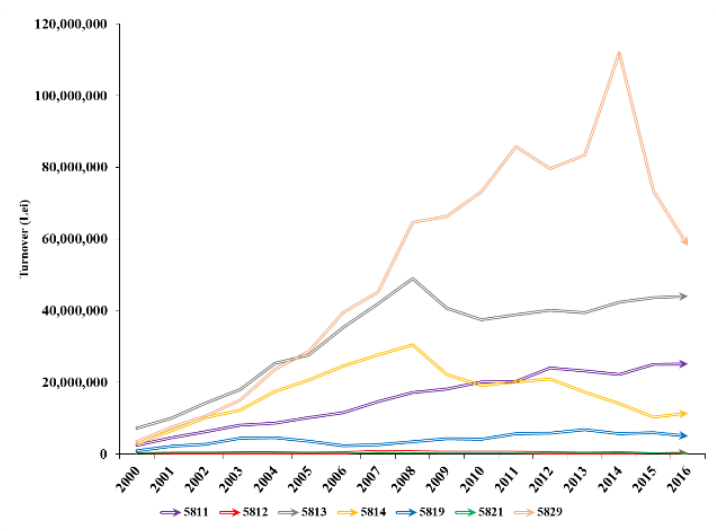

Figure 4. Evolution of the total turnover for NACE codes belonging Publishing area

Source: UB/1423 
The evolution of the total turnover for the Publising class (Fig. 3) presents for the year 2000 values of 303,101,956 lei (at national level), and at regional level a value of 16,878,740 lei for the Center Development Region. The values show an upward trend, with increases until 2008 (3,229,859,940 lei at national level and 3,143,227,458 lei at regional level), with a stagnation and decrease after 2011. In 2018, the maximum national value of 3,952,199,257 lei is registered, and at the level of the region there is a turnover of $143,978,588$ lei.

The evolution of the turnover for NACE codes belonging to Publishing area (Fig. 4) shows 3 codes with important values 5811 - Book publishing (2,473,365 lei in 2000 and 25,168,890 lei in 2016), 5813 - Publishing of newspapers (7,223,256 in 2000 and 44,034.487 lei in 2016) and 5829 - Other software publishing (in 2000 3,378,401 lei and $58,037,383$ lei in 2016).

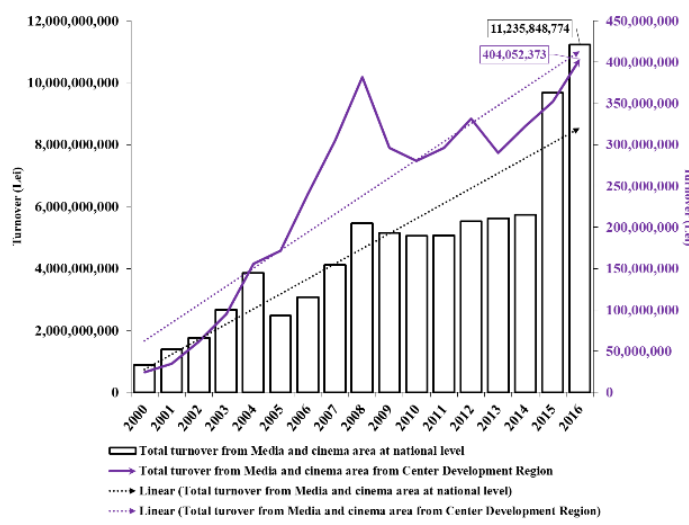

Figure 5. Evolution of the total turnover for Media and cinema area

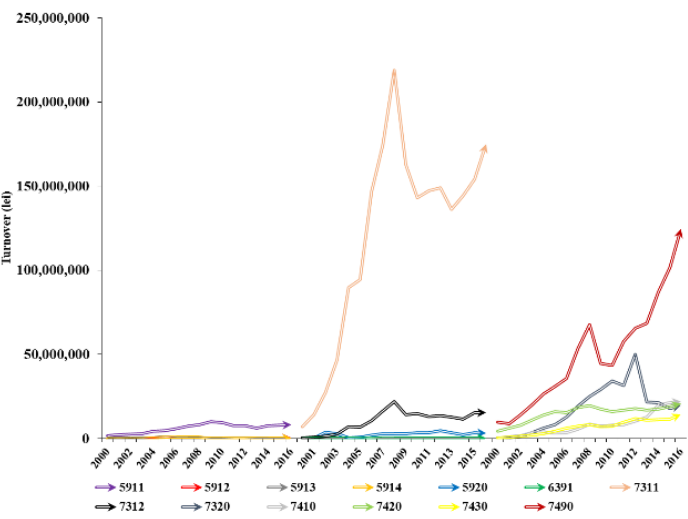

Figure 6. Evolution of the total turnover for NACE codes belonging Media and cinema area Source: UB/1423

The evolution of the total turnover for the Media and cinema class (Fig. 5) presents for the year 2000 values of 892,365,430 lei (at national level), and at the regional level a value of 24,597,321 lei for the Center Development Region. The values show an upward trend, with increases until 2008 and with fluctuations after 2008. In 2018, the national value of $11,235,848,774$ lei is registered and at the regional level a maximum of 404,052,373 lei.

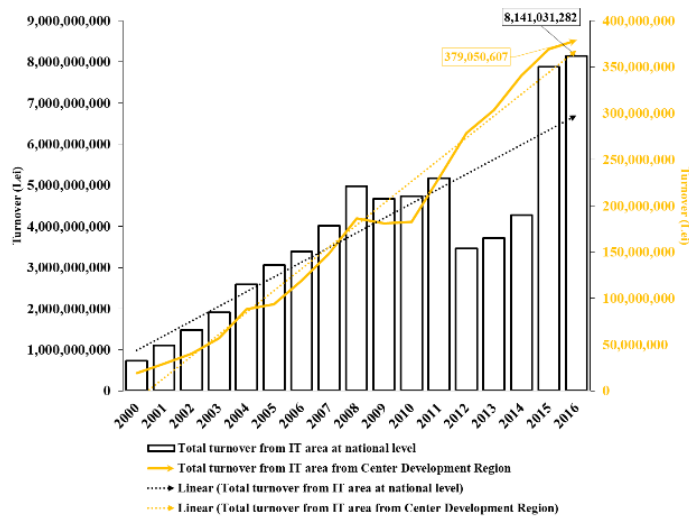

Figure 7. Evolution of the total turnover for IT area

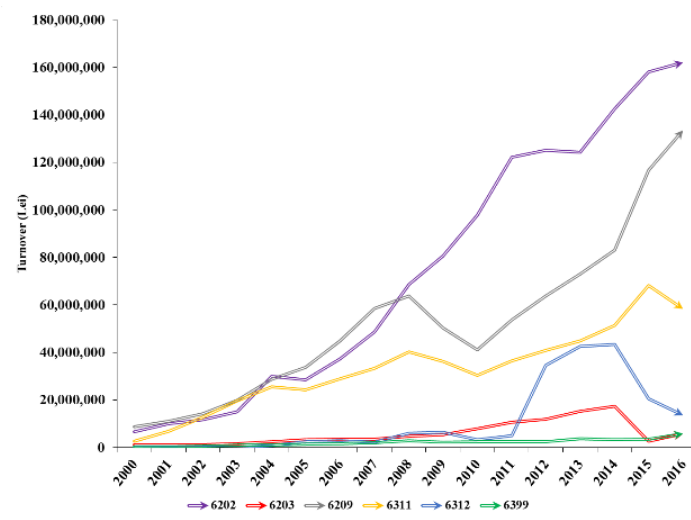

Figure 8. Evolution of the total turnover for NACE codes belonging IT area Source: UB/1423 
The evolution of the turnover for the NACE codes belonging to the Media and cinema area (Fig. 6) shows 2 codes with important values $7311(7,085,405$ lei in 2000 and $174,938,030$ lei in 2016) and 7490 (9,683,648 in 2000 and 124,433,350 lei in 2016).

The IT area (Fig. 7) presents an upward evolution of the values of the turnover with values of 728,557,377 lei in 2000 (at national level) and of 19,505,979 lei in the region. There is a slight decrease due to the economic crisis of 2008, followed by increases in values and in 2016 reached 8,141,031,282 lei at national level and a value of 379,050,607 lei at regional level.

This class has 6 NACE codes (6202 - Computer consultancy activities, 6203 - Computer facilities management activities, 6209 - Other information technology and computer service activities, 6311 - Data processing, hosting and related activities, 6312 - Web portals and 6399 - Other information service activities n.e.c.), the most representative being 6202, the code having an ascending value (Fig. 8).

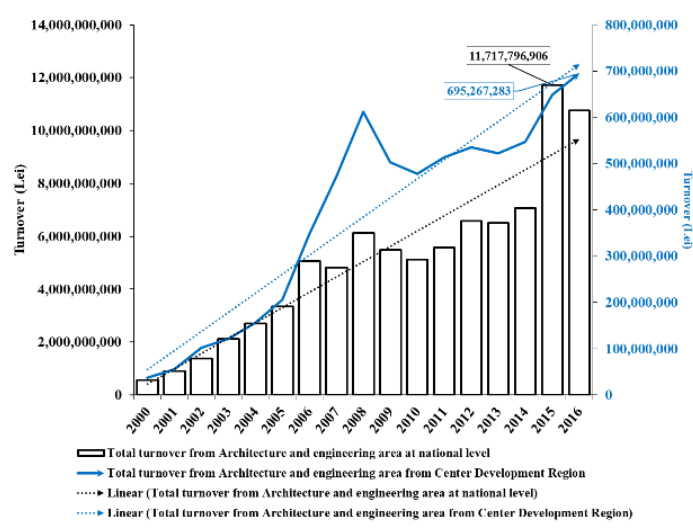

Figure 9. Evolution of the total turnover for Architecture and engineering area

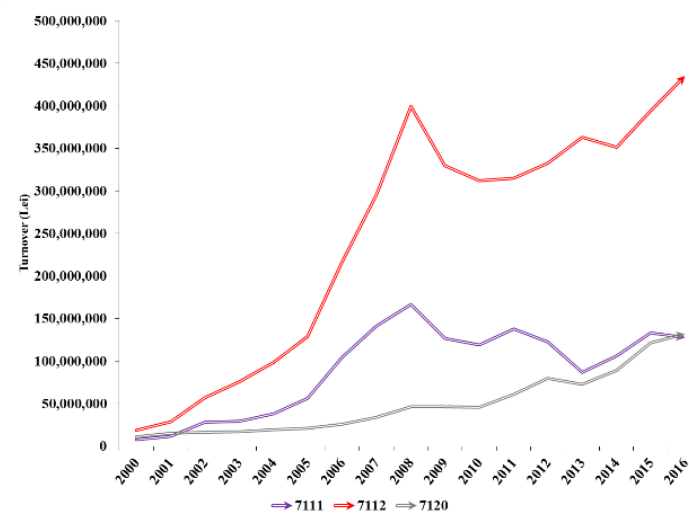

Figure 10. Evolution of the total turnover for NACE codes belonging Architecture and engineering area Source: UB/1423

The evolution of the turnover for the Architecture and engineering area (Fig. 9) presents values of 572,135,514 lei (at national level) and 37,216,181 lei (at the level of the region) for the year 2000, with increases until 2008 being followed by decreases due to the economic crisis $(6,132,702,926-2008$ and 5,490,497,909 - 2009 at the national level and 612,092,681 lei - 2008 and 502,721,925 lei - 2009 at the region level). After 2014, the values begin to grow significantly.

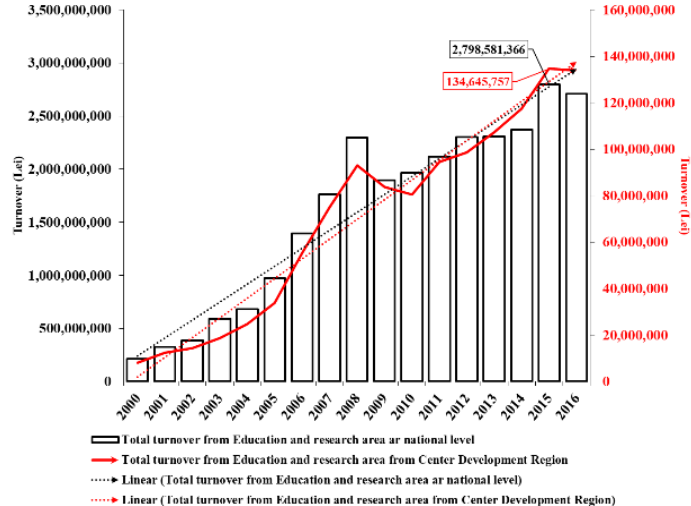

Figure 11. Evolution of the total turnover for Education and research area

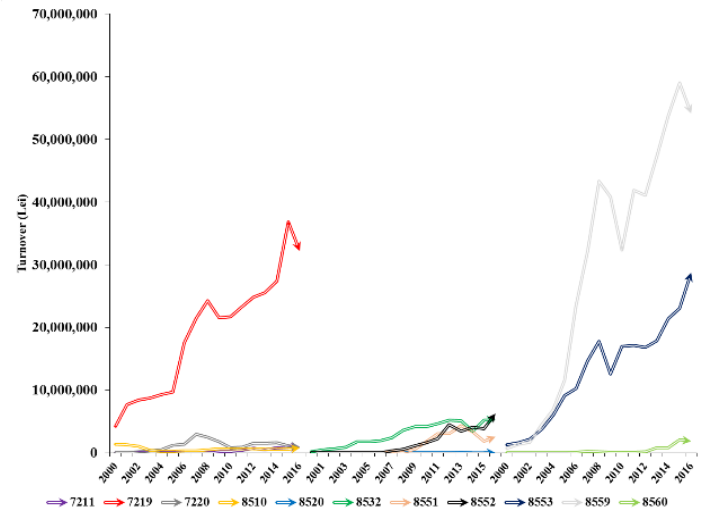

Figure 12. Evolution of the total turnover for NACE codes belonging Education and research area Source: UB/1423 
The most important NACE codes for this class are 7111 - Architectural activities, 7112 Engineering activities and related technical consultancy and 7120 - Technical testing and analysis) (Fig. 10). The highest values of the turnover are found in the code 7112.

For the evolution of the turnover in the Education and research area (Fig. 11), there is a positive trend of the values with slight decreases after 2008, caused by the economic crisis. The values of the turnover for the year 2000 are 211,045,944 lei at national level and 8,032,828 at the region level. In 2016, values of 2,707,496,912 lei are registered at national level and respectively, 1,338,376.21 lei at regional level.

The code with the most significant contribution of the turnover being 8559 - Other education n.e.c. (Fig. 12) with a value of 54,102,143 in 2018.

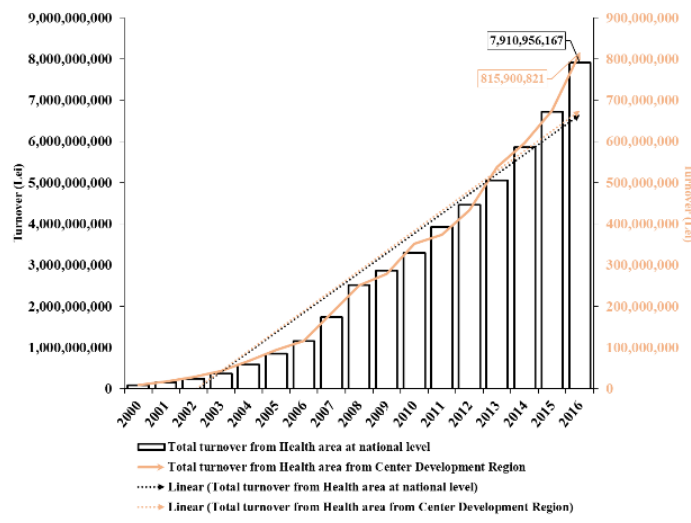

Figure 13. Evolution of the total turnover for Health area

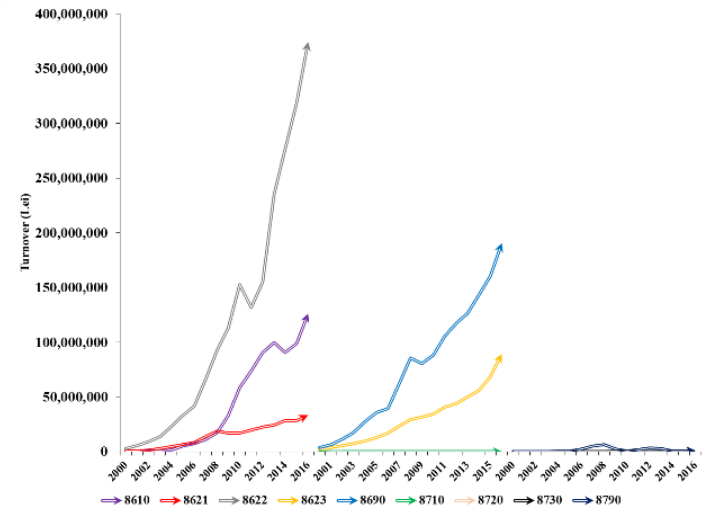

Figure 14. Evolution of the total turnover for NACE codes belonging Health area Source: UB/1423

The evolution of the turnover in the Health field (Fig. 13) shows values of 81,920,271 lei in 2000 at the national level and of 9,621,211 lei in the development region. It presents a positive trend throughout the 17 years analyzed, reaching in 2018 at national values of 7,910,956,167 lei, and at regional level of 815,900,821 lei.

This class has 9 NACE codes (Fig. 14) (8610 - Hospital activities, 8621 - General medical practice activities, 8622 - Specialist medical practice activities, 8623 - Dental practice activities, 8690 - Other human health activities, 8710 - Residential nursing care activities, 8720 - Residential care activities for mental retardation, mental health and substance abuse, 8730 - Residential care activities for the elderly and disabled, 8790 - Other residential care activities, the most important NACE code being 8622, with a value of 374,064,566 lei.

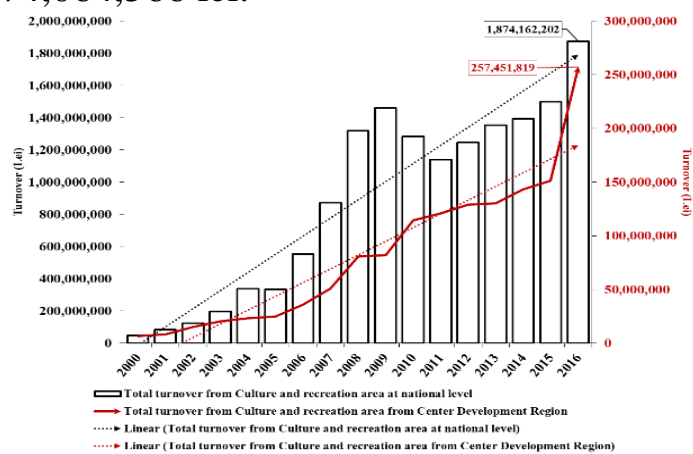

Figure 15. Evolution of the total turnover for Culture and recreation area

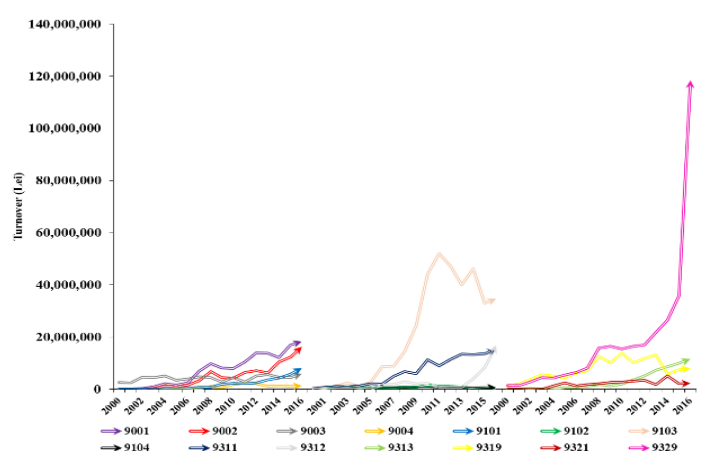

Figure 16. Evolution of the total turnover for NACE codes belonging Culture and recreation area Source: UB/1423 
The evolution of the turnover for the Culture and recreation area (Fig. 15) presents turnover values of 49,432,496 lei at the national level and a value of 6,794,183 lei at the region level. The values follow an upward trend with slight decreases after 2008. The values at national level are 1,318,552,154 lei in 2008 and a slight increase to a value of $1,460,329,051$ lei in 2009. The growth is also felt at the level of the region where the turnover is 80,925,577 lei in 2008 and of 82,065,762 lei in 2009. The values peaks at both national and regional levels are registered in $2018(1,874,162,202$ lei and 257,451,819 lei respectively).

Culture and recreation area (Fig. 16) totals 14 NACE codes, the one with the most significant values is 9329 (with 118,390,64 lei in 2016).

\section{Aknowledgement}

This paper is co-financed from the Human Capital Operational Program 2014-2020, project number POCU / 380/6/13/125245 no. 36482 / 23.05.2019 "Excellence in interdisciplinary $\mathrm{PhD}$ and post- $\mathrm{PhD}$ research, career alternatives through entrepreneurial initiative (EXCIA)", coordinator The Bucharest University of Economic Studies".

\section{CONCLUSION}

Approach the spatial dimension of the main creative economic indicators highlights two specificities. First of all, the tendency of concentration of creative economies in the main urban centers and in the emerging space structured around them, significant being the concentration of values in the cities of Brașov, Târgu Mureș and Sibiu, as well as around them. Secondly, we notice the spectacular increases of the analyzed indicators.

Detailed analyzes revealed structural changes in the economic activities of the creative sector, especially in the big urban centers, as well as their movement outside the cities, along the main axes of circulation.

Future research should focus on the detailed analysis of the role of creative economies in local and regional development using modern methodologies, which have resulted in other research on analyzing the relationships between the components of the territorial system [24], [25], [26], [27], [28], [29], [30], [31], [32].

\section{REFERENCES}

[1] Jakob D., van Heur B. Editorial: Taking Matters into Third Hands: Intermediaries and the Organization of the Creative Economy. Regional Studies, vol. 49, pp 357-361, 2014.

[2] Howkins J. Creative Economy: How People Make Money From Ideas, 3rd ed., Penguin Books, London, Great Britain, 2013, pp 17. In Chung, N.; Leeb H., Jae Lee S., Kooa C. The influence of tourism website on tourists' behavior to determine destination selection: A case study of creative economy in Korea, Technological Forecasting and Social Change, vol. 96, pp 130143, 2015.

[3] Florida R. The rise of the creative class. Basic Books, New York, NY, 2002.

[4] Batabyal A., Nijkamp P. Richard Florida's creative capital in a trading regional economy: a theoretical investigation, Annals of Regional Science, vol. 44, pp 241-250, 2010.

[5] Boschma R.A., Fritsch M. Creative class and regional growth. Empirical evidence from seven European countries. Economic Geography, vol. 85, 391-423, 2009.

[6] Clifton N. Cooke P. Creative knowledge workers and location in Europe and North America: a comparative review. Creative Industries Journal, 2010.

[7] Florida R., Tinagli I. Europe in the Creative Age. London: Demos, 2004. 
[8] Tödtling F., Asheim B., Boschma R. Knowledge sourcing, innovation and constructing advantage in regions of Europe. European Urban and Regional Studies, vol. 20, pp161-169, 2013.

[9] Deheinzelin L. Economia Criativa e Métodos para Dar uma Mão ao Futuro, Redige, vol. 2, pp 343-360, 2010. In Fachinelli A.C., Carrillo F.J., D’Arisbo A., Capital system, creative economy and knowledge city transformation: Insights from Bento Gonçalves, Brazil, Expert Systems with Applications, vol. 41, pp 5614-5624, 2014.

[10] Abankina T. Regional development models using cultural heritage resources, International Journal of Culture, Tourism and Hospitality Research, vol. 7, pp 3-10, 2013.

[11] Shuaib A.A. Enoch O.F., Creative industry: Its involvement in business world, Advances in Asian Social Science, vol. 3, pp 1-6, 2012.

[12] Handke C. W. Measuring Innovation in Media Industries: Insights Froma Survey of German Record Companies, 2004, Humboldt-University, Berlin and Erasmus University, Rotterdam In Bae S. H., Yoo K., Economic modeling of innovation in the creative industries and its implications, Technological Forecasting \& Social Change, vol. 96, pp 101-110, 2015.

[13] Handke C.W. Surveying Innovation in the Creative Industries, 2006, Humboldt-University, Berlin and Erasmus University, Rotterdam In Bae S. H., Yoo K., Economic modeling of innovation in the creative industries and its implications, Technological Forecasting \& Social Change, vol. 96, pp 101-110, 2015.

[14] Galenson D.W. Analyzing artistic innovation: the greatest breakthroughs of the twentieth century, 2006, NBER Working Paper, National Bureau of Economic Research, Cambridge In Bae S. H., Yoo K., Economic modeling of innovation in the creative industries and its implications, Technological Forecasting \& Social Change, vol. 96, pp 101-110, 2015.

[15] Stoneman P. An introduction to the definition and measurement of soft innovation, 2007, NESTA Working Paper. National Endowment for Science, Technology and the Arts, London In Bae S. H., Yoo K. Economic modeling of innovation in the creative industries and its implications, Technological Forecasting \& Social Change, vol. 96, pp 101-110, 2015.

[16] Wilkinson A. An Assessment of Productivity Indicators for the Creative Industries, 2007, DCMS, London In Bae S. H., Yoo K. Economic modeling of innovation in the creative industries and its implications, Technological Forecasting \& Social Change, vol. 96, pp 101-110, 2015.

[17] Bakhshi H., McVittie E., Simmie J. Creating innovation. Do the creative industries support innovation in the wider economy?, 2008, NESTA Research Report March 2008, National Endowment for Science, Technology and the Arts, London In Bae S. H., Yoo K. Economic modeling of innovation in the creative industries and its implications, Technological Forecasting \& Social Change, vol. 96, pp 101-110, 2015.

[18] Müller K., Rammer C., Trüby J. The role of creative industries in industrial innovation, Innovation, vol. 11, 148-168, 2009.

[19] Cohen W.M., Levinthal D.A. Innovation and learning: the two faces of R\&D, Economic Journal, vol. 99, pp 569-596, 1989.

[20] Cohen W.M., Levinthal D.A. Absorptive capacity: a new perspective on learning and innovation, Administrative Science Quarterly, vol. 35, pp 128-152, 1990.

[21] Howkins J. The Creative Economy: How People Make Money From Ideas, Allen Lane/Penguin Press, 2001.

[22] Florida R. L. The Rise of the Creative Class: And How It's Transforming Work, Leisure, Community and Everyday Life. New York, NY: Basic Books, 2002.

[23] The New England Council, 2000, The Creative Economy Initiative: The Role of the Arts and Culture in New England's Economic Competitiveness. 
[24] Prăvălie R., Sîrodoev I., Patriche C. V., Bandoc G., \& Peptenatu D. The analysis of the relationship between climatic water deficit and corn agricultural productivity in the Dobrogea plateau, Carpathian Journal of Earth and Environmental Sciences, vol. 9, pp 201-2014, 2014.

[25] Pintilii R.D., Andronache I., Simion A.G., Drăghici C.C., Peptenatu D., Ciobotaru A.M., Dobrea R.C. \& Papuc R.M. Determining forest fund evolution by fractal analysis (SuceavaRomania), Urbanism Architecture Constructions, vol. 7, pp 31-42, 2016.

[26] Pintilii R.D., Andronache I., Diaconu D.C., Dobrea R.C., Zelenakova M., Fensholt R., Peptenatu D., Draghici C.C. \& Ciobotaru A.M. Using Fractal Analysis in Modeling the Dynamics of Forest Areas and Economic Impact Assessment: Maramures County, Romania, as a Case Study, Forests, vol. 8, 2017.

[27] Pintilii R.D., Peptenatu D., Draghici C., Irina S., Stoian R.D., Structural Changes in The Entrepreneurial Profile of The Creative Industries in Romania, 2nd Global Conference on Business, Economics, Management and Tourism, Edited by:Iacob, AI, Procedia Economics and Finance, Vol. 23, pp: 1147-1151, 2015.

[28] Prăvălie R., Patriche C.V., Sîrodoev I., Bandoc G., Dumitraşcu M. \& Peptenatu D. Water deficit and corn productivity during the post-socialist period. Case study: Southern Oltenia drylands, Romania, Arid Land Research and Management, vol. 30, pp 239-257, 2016.

[29] Andronache I., Fensholt R., Ahammer H., Ciobotaru A.M., Pintilii R.D., Peptenatu D., Drăghici C.C., Diaconu D. C., Radulovic M., Pulighe G., Azihou A.F., Toyi M.S. \& Sinsin B. Assessment of Textural Differentiations in Forest Resources in Romania Using Fractal Analysis, Forests, vol. 8, 2017.

[30] Drăghici C.C., Andronache I., Ahammer H., Peptenatu D., Pintilii R.D., Ciobotaru A.M., Simion A.G., Dobrea R.C., Diaconu D.C., Vişan M.C., Papuc R.M. Spatial evolution of forest areas in the northern Carpathian Mountains of Romania, Acta Montanistica Slovaca, vol. 22, pp 95-106, 2017.

[31] Gruia A.K., Dobrea R.C., Simion C.P., Dima C., Grecu A., Hudea O.S., Marin M., Andronache I., Peptenatu D. The Use of Sholl and Kolmogorov Complexity Analysis in Researching on the Sustainable Development of Creative Economies in the Development Region of Bucharest-Ilfov, Romania, Sustainability, vol. 11, 6195, 2019. DOI: doi:10.3390/su11226195

[32] Grecu A., Gruia A.K., Marin M., Bănuță M., Olteanu C., Constantin I., Gadoiu M., Teodorescu C., Dobrea R.C., Drăghici C.C., Specificity of Sustainable Structural Dynamics of Local Economy in Romanian Tourist Resorts, Sustainability, vol. 11, 7155, 2019. DOI: doi:10.3390/su11247155 